\title{
Analisis Kebijakan Pemerintah Arab Saudi Menaikan Tarif Bea Masuk dan Implikasinya Terhadap Ekspor Indonesia
}

\author{
Rahayu Ningsih', Choirin Nisaa² \\ Pusat Pengkajian Perdagangan Luar Negeri, Kementerian Perdagangan \\ email: rahayuningsih75@gmail.com
}

\begin{abstract}
Abstrak
Arab Saudi merupakan mitra dagang Indonesia dengan total nilai perdagangan pada tahun 2019 tercatat sebesar USD 5,07 miliar. Perdagangan Indonesia dengan Arab Saudi menyumbang defisit terhadap neraca perdagangan Indonesia yakni dari USD 1,36 miliar di tahun 2015 naik menjadi USD 3,68 miliar di tahun 2018. Untuk itu pemerintah terus berupaya meningkatkan kinerja ekspor Indonesia ke Arab Saudi sehingga hal ini dapat menurunkan defisit neraca perdagangan. Namun di tengah upaya pemerintah tersebut, pada tanggal 27 Mei 2020, pemerintah Arab Saudi khususnya otoritas Bea Cukai Saudi mengeluarkan kebijakan perubahan besaran tarif bea masuk terhadap 37 pos tarif (HS 2 digit) dengan kenaikan menjadi pada kisaran $7 \%$ hingga $20 \%$ dari besaran tarif awal yakni kisaran 5\% hingga 12\%. Hal ini tentu akan berpotensi mempengaruhi penetrasi ekspor Indonesia. Untuk itu studi ini bertujuan untuk mengidentifikasi produk ekspor Indonesia yang mengalami kenaikan tarif bea masuk di Arab Saudi dan menganalisis dampaknya terhadap kinerja ekspor Indonesia. Metode yang digunakan adalah analisis deskriptif dengan menggunakan data sekunder berupa data perdagangan yang bersumber dari Badan Pusat Statistik dan Trademap UN Comtrade. Hasil kajian menyimpulkan bahwa kenaikan tarif bea masuk Arab Saudi terhadap produk ekspor utama Indonesia berdampak pada beberapa kelompok produk ekspor Indonesia yakni produk kertas, benda-benda dari besi dan baja, besi dan baja, mesin-mesin / pesawat mekanik, dan serat stapel buatan. Sementara untuk produk ekspor utama lainnya seperti, kendaraan dan bagiannya, produk plastik, produk elektronik, minyak sawit, produk daging dan ikan olahan, serta sebagian produk tekstil tidak berdampak. Oleh karena itu, untuk mengantisipasi dampak terhadap penetrasi produk ekspor Indonesia, maka pemerintah perlu melakukan sosialisasi kepada pelaku usaha khususnya eksportir yang produknya dikenakan kenaikan tarif bea masuknya di Arab Saudi sehingga dapat dilakukan langkah antisipasi dan upaya untuk mencari alternatif pasar tujuan ekspor di negara lain. Selain itu perlu adanya upaya negosiasi kepada pemerintah Arab Saudi terkait potensi hambatan bagi produk Indonesia yang akan terdampak.
\end{abstract}

Keywords: tarif bea masuk, Arab Saudi, kinerja ekspor, produk ekspor Indonesia

\begin{abstract}
Saudi Arabia is Indonesian trading partner with a total trade value in 2019 reached USD 5.07 billion. Indonesia's trade with Saudi Arabia contributed to a deficit in Indonesia's trade balance, from USD 1.36 billion in 2015 to USD 3.68 billion in 2018. Amid efforts to increase exports to Saudi Arabia, on May 27, 2020, Custom Saudi, has issued a policy of changing the rate of import duty on 37 tarif lines (HS 2 digit) with an increase to be in the range of $7 \%$ to $20 \%$ from the initial rate, which is in the range of $5 \%$ to $12 \%$. This matter, of course, has potential effect on Indonesia's export penetration. This analysis aims to identify Indonesian export products that are affected by the increase in import


duty rates in Saudi Arabia and analyze the impact of the increase in the import duty of Saudi Arabia and its implications for Indonesia's export performance. With the descriptive analysis method using secondary data of trade data sourced from the Central Bureau of Statistics and UN Comtrade, this study concluded that the increase in Saudi Arabia's import duties on Indonesia's main export products had an impact on several of Indonesia's main export products, namely paper products, iron and steel products, iron and steel, Man-made staple fibres, and Machinery. Meanwhile, other export products such as automotive, plastic product, Electrical machinery, palm oil, processed meat and fish products, and some textile products have no substantial impact. Therefore, to anticipate the impact on the penetration of Indonesian export products, the government needs to disseminate information to business actors, especially exporters whose products are subject to an increase in import duty in Saudi Arabia so that anticipatory steps can be taken as well as efforts to find alternative export destination markets in other countries.

Keywords: import duty, Saudi Arabia, export performance, Indonesia's export product

(C) 2020 Pusdiklat Perdagangan. All rights reserved

\section{PENDAHULUAN}

Arab Saudi merupakan salah satu negara mitra dagang utama Indonesia yang menempati urutan ke 20 sebagai negara tujuan utama ekspor Indonesia. Sementara sebagai negara asal impor, Arab Saudi menempati urutan ke 12 di Indonesia. Total nilai perdagangan Indonesia dengan Arab Saudi pada tahun 2019 mencapai USD 5,07 miliar dimana nilai ekspor Indonesia sebesar USD 1,5 miliar sedangkan impornya sebesar USD 3,57 miliar sehingga neraca perdagangan tercatat defisit sebesar USD 2,06 miliar. Selamat tahun 2016-2019, tercatat bahwa defisit neraca perdagangan terbesar terjadi pada tahun 2018 yakni mencapai USD 3,69 miliar.

Perdagangan Indonesia dengan Arab Saudi tercatat defisit terutama satu dekade terakhir dengan nilai terus meningkat yakni dari USD 1,36 miliar di tahun 2015 naik menjadi USD 3,68 miliar di tahun 2018. Hal ini tentu menjadi prioritas bagi pemerintah untuk terus meningkatkan kinerja ekspor Indonesia ke Arab Saudi sehingga hal ini dapat menurunkan defisit neraca perdagangan Indonesia dengan Arab Saudi.

Di tengah upaya pemerintah Indonesia untuk terus meningkatkan kinerja ekspor di pasar non tradisional termasuk Arab Saudi, pemerintah Arab Saudi khususnya Custom Saudi (Otoritas Bea Cukai Saudi) pada tanggal 27 Mei 2020 telah mengeluarkan kebijakan baru yakni berupa perubahan besaran tarif bea masuk terhadap 37 pos tarif (HS 2 digit) dengan kenaikan menjadi pada kisaran $7 \%$ hingga $20 \%$ dari besaran tarif awal yakni kisaran $5 \%$ hingga 12\%. Kebijakan tersebut mulai berlaku efektif sejak tanggal 10 Juni 2020. Hal ini tentu akan berdampak pada kinerja ekspor Indonesia ke Arab Saudi mengingat pada tahun 2018 lalu pemerintah Arab Saudi juga telah mengeluarkan kebijakan yang mewajibkan setiap negara pengekspor untuk mendaftarkan Competent Authority yang menangani produk makanan dan obat di setiap negara asal ke badan otoritasnya yakni Saudi Food and Drug Authority (SFDA). Akibat kebijakan tersebut dilaporkan oleh asosiasi produk makanan dan minuman bahwa ekspor dari Indonesia mengalami hambatan untuk masuk ke pasar Arab Saudi.

Kebijakan suatu negara dalam menaikkan tarif bea masuknya juga dilakukan oleh negara lain seperti Amerika Serikat. Setelah mendapati kenyataan bahwa baja yang dikonsumsi oleh industri di Amerika Serikat sepertiganya adalah berasal dari impor begitu pula halnya dengan alumunium yang 90 persen kebutuhan domestiknya didatangkan dari impor, akhirnya Presiden Trump pada Maret 2018 memberlakukankebijakan menaikkan tarif baja sebesar $25 \%$ dan tarif alumunium sebesar $10 \%$. Pengenaan kenaikan tarif hanya diberlakukan pada beberapa negara yakni RRT, Uni Eropa, Kanada, dan Meksiko. Dalam studinya dengan 
menggunakan metode deskriptif analisis, Minardiet al (2019) menyimpulkan bahwa Indonesia dapat diuntungkan untuk melakukan penetrasiproduk baja dan alumuniumnya di pasar Amerika Serikat menggantikan RRT sepanjang dapat memenuhi kualitas standard yang diterapkan.

Kebijakan pemerintah Arab Saudi menaikkantarif bea masuk atas beberapa produk kemungkinan dilandasi oleh menurunnya dayasaing produk Arab Saudi di pasar global. Menurut Jasimuddin (2001), meskipun pemerintah Arab Saudi sangat mendukung ekonomi pasar bebas berdasarkan persaingan, namun Arab Saudi belum berhasil di dalam persaingan global sehingga menuntut adanya peninjauan ulang terhadap keunggulan kompetitif yang dimiliki oleh industri domestiknya. Alasan lain yang melandasi kebijakan menaikkkan tarif dimungkinkan karena adanya kebijakan nasional dalam memperkuat dan mendorong industri domestiknya setelah tidak lagi mengandalkan kepada sumber daya alam berupa minyak sebagai mana tertuang dalam laporan UNIDO (2006).

Menindaklanjuti kebijakan yang diterbitkan oleh pemerintah Arab Saudi, pemerintah Indonesia yakni Kementerian Luar Negeri RI melalui surat No. 06089/BK/06/2020/31 telah meminta kepada Kementerian Perdagangan untuk menganalisis dampak terhadap perdagangan Indonesia terkait kebijakan Arab Saudi yang menaikkan tarif bea masuk untuk beberapa jenis produknya. Oleh karena itu studi ini bertujuan untuk mengidentifikasi produk ekspor Indonesia yang mengalami kenaikan tarif bea masuk di Arab Saudi dan menganalisis dampaknya terhadap kinerja perdagangan khususnya ekspor Indonesia.

\section{METODOLOGI}

\section{Metode Analisis}

Analisis ini dilakukan menggunakan metode analisis deskriptif berdasarkan data perdagangan Indonesia. Untuk data yang bersumber dari Trade map maka data yang digunakan adalah data periode 2015-2019 sedangkan untuk data yang bersumber dari
BPS digunakan data pada periode 2015 hingga Januari-Oktober 2020.

Analisis deskriptif merupakan analisis yang paling mendasar untuk menggambarkan keadaan data secara umum. Analisis deskriptif ini meliputi beberapa hal, yakni distribusi frekuensi, pengukuran tendensi pusat, dan penguraian variabilitas (Wiyono, 2001). Sementara itu, metode deskriptif adalah suatu metode penelitian yang dilakukan untuk mengetahui keberadaan variabel mandiri, baik hanya pada satu variabel atau lebih (variabel yang berdiri sendiri) dan mencari hubungan variabel itu dengan variabel yang lain (Sugiyono, 2009). Dalam penelitian ini, variabel yang diamati adalah tarif bea masuk sebagai independent variabel dan kinerja ekspor sebagai dependent variabel Dari pengertian tersebut dapat disimpulkan bahwa metode deskriptif dengan pendekatan kuantitatif merupakan metode yang bertujuan menggambarkan secara sistematis dan faktual tentang fakta-fakta serta hubungan antar variabel yang diselidiki dengan cara mengumpulkan data, mengolah, menganalisis, dan menginterpretasi data dalam pengujian hipotesis statistik.

Dalam analisis deskriptif kuantitatif, data-data disajikan dalam bentuk tabel, diagram, grafik, dan lain-lain. Hal ini ditujukan untuk mempermudah memahami data-data yang disajikan. Dalam ilmu perencanaan, penggunaan statistik deskriptif dapat dilakukan untuk mempermudah penyampaian informasi agar mudah diterima dan dipahami. Data yang dibutuhkan adalah data yang sesuai dengan masalah-masalah yang ada dan sesuai dengan tujuan penelitian, sehingga dapat diketahui mengenai pengaruhnya dengan berdasarkan teori dan pengujian hipotesis (Wiyono, 2001).

Penelitian ini menggunakan metode tersebut karena bertujuan untuk menggambarkan dengan jelas bagaimana pengaruh penerapan kebijakan tarif bea masuk atas produk-produk tertentu terhadap potensi dampak atas kinerja ekspor Indonesia. Data kinerja perdagangan dihitung pertumbuhan dan pangsanya, kemudian disajikan dalam bentuk tabel dan grafik. Kemudian nilai-nilai 
pada tabel dan grafik dijelaskan secara deskriptif untuk mencari makna, membuat pola-pola, penjelasan, alur sebab akibat, dan proposisi.

Untuk menjawab tujuan pertama yakni mengidentifikasi produk ekspor Indonesia yang mengalami kenaikan tarif bea masuk, dilakukan inventarisasi produk apa saja yang tarifnya dinaikkan berdasarkan data tarif dari Custom Saudi. Sementara untuk tujuan kedua, dilakukan tabulasi produk yang dinaikkan tarifnya dengan kinerja ekspornya. Selain itu juga dianalisis seberapa banyak pos tarif yang terdampak dan berapa besar pangsanya terhadap nilai ekspor secara keseluruhan. Dampak yang dimaksud dalam studi ini adalah potensi penurunan ekspor yang kemungkinan dirasakan eksportir pasca penerapan tarif yang baru.

\section{Data dan Teknik Pengumpulan Data}

Data yang digunakan dalam analisis ini adalah data sekunder berupa data perdagangan yang bersumber dari Badan Pusat Statistik dan Trademap UN Comtrade. Data lainnya yang digunakan adalah data tarif bea masuk Arab Saudi yang berasal dari Custom Saudi.
Selain data yang bersumberdari BPS, UN Comtrade dan Custom Saudi, data dan informasilainnya diperoleh dari berbagai sumber lainnya seperti website World Trade Organization (WTO) dan PerwakilanPerdagangan Indonesia (Atase dan ITPC).

\section{HASIL DAN PEMBAHASAN}

\section{Gambaran Umum Perdagangan Arab Saudi}

Berdasarkan data Trademap UN Comtrade sebagaimana terdapat pada Tabel 1, total ekspor Arab Saudi ke dunia pada tahun 2019 adalahsebesar USD 251,8 miliar atau turun 14,5\% disbanding tahun sebelumnya. Selama lima tahun terakhir, ekspor Arab Saudi meningkat dengan rata-rata kenaikan sebesar $8,7 \%$ per tahun. Sebagian besar ekspor ditujukan ke negara-negara dalam klasifikasi Area Nes (area not elsewhere classified/negara lainnya) dengan pangsa mencapai 80,4\% kemudian disusul RRT (3,7\%); UEA (1,7\%); India (1,5\%) dan Singapura $(1,4 \%)$. Adapun ekspor Arab Saudi ke Indonesia relatif kecil yakni hanya bernilai USD 502 juta atau $(0,2 \%$ dari total ekspor Arab Saudi). Indonesia menempati urutan ke 28 sebagai negara tujuan ekspor Arab Saudi

\section{Tabel 1. Perkembangan Ekspor Arab Saudi ke Dunia Berdasarkan Negara}

\begin{tabular}{|c|c|c|c|c|c|c|c|c|c|}
\hline \multirow{2}{*}{ No } & \multirow{2}{*}{ Negara Pengimpor } & \multicolumn{5}{|c|}{ Nilai: USD Juta } & \multirow{2}{*}{\begin{tabular}{|c|} 
Growth \\
'19/'18 (\%)
\end{tabular}} & \multirow{2}{*}{\begin{tabular}{|c|}
$\begin{array}{c}\text { Trend '15- } \\
\text { '19 (\%) }\end{array}$ \\
\end{tabular}} & \multirow{2}{*}{\begin{tabular}{|c|} 
Share \\
$2019(\%)$ \\
\end{tabular}} \\
\hline & & 2015 & 2016 & 2017 & 2018 & 2019 & & & \\
\hline & Total Ekspor & 213.376 & 178.874 & 220.069 & 294.536 & 251.800 & $-14,5$ & 8,7 & 100,0 \\
\hline 1 & Area Nes & 164.557 & 9.057 & 170.627 & 231.584 & 202.428 & $-12,6$ & 44,1 & 80,4 \\
\hline 2 & China & 5.608 & 4.136 & 5.970 & 9.724 & 9.340 & $-4,0$ & 20,6 & 3,7 \\
\hline 3 & United Arab Emirates & 6.773 & 6.567 & 7.687 & 8.132 & 4.377 & $-46,2$ & $-6,4$ & 1,7 \\
\hline 4 & India & 3.003 & 2.458 & 2.607 & 3.565 & 3.773 & 5,8 & 8,6 & 1,5 \\
\hline 5 & Singapore & 2.356 & 2.219 & 3.067 & 4.020 & 3.414 & $-15,1$ & 14,3 & 1,4 \\
\hline 6 & Turkey & 1.724 & 1.507 & 1.734 & 2.276 & 1.993 & $-12,4$ & 7,3 & 0,8 \\
\hline 7 & Belgium & 1.507 & 1.290 & 1.707 & 2.486 & 1.821 & $-26,8$ & 10,9 & 0,7 \\
\hline 8 & Egypt & 1.973 & 1.525 & 1.402 & 2.025 & 1.687 & $-16,7$ & $-0,3$ & 0,7 \\
\hline 9 & Kuwait & 1.574 & 1.758 & 1.959 & 2.086 & 1.624 & $-22,1$ & 2,4 & 0,6 \\
\hline \multirow[t]{2}{*}{10} & Malaysia & 1.354 & 1.241 & 1.210 & 1.584 & 1.361 & $-14,0$ & 2,6 & 0,5 \\
\hline & Subtotal (10 Negara) & 190.430 & 31.757 & 197.970 & 267.482 & 231.818 & $-13,3$ & 28,7 & 92,1 \\
\hline \multirow[t]{2}{*}{28} & Indonesia & 324 & 504 & 439 & 584 & 502 & $-14,1$ & 10,8 & 0,2 \\
\hline & Lainnya & 22.623 & 146.613 & 21.660 & 26.469 & 19.481 & $-26,4$ & $-18,2$ & 7,7 \\
\hline
\end{tabular}

Sumber: Trademap (2020), diolah 
Sementara produk utama ekspor non migas Arab Saudi adalah berupa Produk Kimia seperti Polypropylene (pangsa 2,2\%), Polyethylene (pangsa 3,5\%), Monobutyl ethers (pangsa $1,1 \%)$, dan Anhydrous ammonia (0,7\%).

Tabel 2. Perkembangan Ekspor Arab Saudi ke Dunia Berdasarkan Produk

\begin{tabular}{|c|c|c|c|c|c|c|c|c|c|c|}
\hline \multirow{2}{*}{ No } & \multirow{2}{*}{ HS } & \multirow{2}{*}{ Deskripsi } & \multicolumn{5}{|c|}{ Nilai: USD Juta } & \multirow{2}{*}{\begin{tabular}{|l|} 
Growth (\%) \\
$2019 / 2018$ \\
\end{tabular}} & \multirow{2}{*}{\begin{tabular}{|c|} 
Tren(\%) \\
$2015-2019$ \\
\end{tabular}} & \multirow{2}{*}{\begin{tabular}{|c|} 
Share (\%) \\
2019 \\
\end{tabular}} \\
\hline & & & 2015 & 2016 & 2017 & 2018 & 2019 & & & \\
\hline & & Total Impor & 213.376 & 178.874 & 220.069 & 294.536 & 251.800 & $-14,5$ & 8,7 & 100,0 \\
\hline 1 & 390210 & Polypropylene, in primary forms & 5.046 & 4.221 & 4.842 & 5.836 & 5.428 & $-7,0$ & 4,8 & 2,2 \\
\hline 2 & 390120 & $\begin{array}{l}\text { Polyethylene with a specific gravity } \\
\text { of }>=0,94 \text {, in primary forms }\end{array}$ & 4.579 & 4.154 & 4.969 & 5.322 & 4.787 & $-10,1$ & 3,4 & 1,9 \\
\hline 3 & 390110 & $\begin{array}{l}\text { Polyethylene with a specific gravity } \\
\text { of }<0,94 \text {, in primary forms }\end{array}$ & 3.384 & 3.582 & 3.706 & 5.152 & 4.147 & $-19,5$ & 8,0 & 1,6 \\
\hline 4 & 290943 & $\begin{array}{l}\text { Monobutyl ethers of ethylene } \\
\text { glycol or of diethylene glycol }\end{array}$ & 3.003 & 2.234 & 2.897 & 3.513 & 2.807 & $-20,1$ & 3,2 & 1,1 \\
\hline 5 & 281410 & Anhydrous ammonia & 1.245 & 525 & 273 & 1.542 & 1.648 & 6,9 & 17,8 & 0,7 \\
\hline 6 & 290250 & Styrene & 1.356 & 1.287 & 1.313 & 1.242 & 1.500 & 20,7 & 1,7 & 0,6 \\
\hline 7 & 290531 & Ethylene glycol "ethanediol" & 1.040 & 338 & 458 & 1.124 & 1.306 & 16,2 & 18,0 & 0,5 \\
\hline 8 & 290511 & Methanol "methyl alcohol" & 1.149 & 778 & 1.078 & 1.444 & 1.200 & $-16,9$ & 7,3 & 0,5 \\
\hline 9 & 310210 & $\begin{array}{l}\text { Urea, whether or not in aqueous } \\
\text { solution (excluding that in pellet or } \\
\text { similar forms }\end{array}$ & 1.049 & 861 & 901 & 1.227 & 1.101 & $-10,3$ & 4,6 & 0,4 \\
\hline 10 & 290243 & P-Xylene & 145 & 45 & 41 & 635 & 1.005 & 58,3 & 91,6 & 0,4 \\
\hline & Lainnya & & 191.382 & 160.848 & 199.590 & 267.497 & 226.871 & $-15,2$ & 8,9 & 90,1 \\
\hline
\end{tabular}

Sumber: Trade map (2020), diolah

Pada tabel 3 terlihat bahwa total impor Arab Saudi dari dunia di tahun 2019 tercatat sebesar USD 144,3 miliar atau naik $6,7 \%$ dibanding tahun sebelumnya. Namun jika dilihat selama lima tahun terakhir, nilai impor mengalami penurunan rata-rata sebesar $2,8 \%$ per tahun. Negara pemasok utama adalah RRT denganpangsa sebesar 18,8\%. Selama periode tahun 2015-2019, nilai impor Arab Saudi dari RRT meningkat rata-rata sebesar $4,1 \%$ per tahun. Hal ini menunjukkan bahwa RRT memiliki posisi yang cukup kuat di pasar Arab Saudi. Amerika Serikat juga memiliki pangsa yang cukup besar yakni 11,8\%, namun tren impor Arab Saudi dari
Amerika Serikat cenderung menurun denganlaju penurunan rata-rata $4,6 \%$ per tahun. Sementara negara pemasok ketiga adalah Uni Emirat Arab dengan pangsa sebesar $7 \%$ disusul Jerman dan Jepang dengan pangsa masing-masing sebesar $4,9 \%$ dan $4,5 \%$. Indonesia sendiri berada pada urutan ke-16 sebagai negara asal impor Arab Saudi dengan pangsa sekitar 1,5\%. Pada tahun 2019, impor dari Indonesia meningkat $37,1 \%$ dibanding tahun lalu. Namun demikian, tren impor Arab Saudi dari Indonesia selama 5 tahun terakhir menurun dengan penurunan rata-rata per tahun sebesar $3,9 \%$. 
Tabel 3. Perkembangan Impor Arab Saudi dari Dunia Berdasarkan Negara

\begin{tabular}{|c|c|c|c|c|c|c|c|c|c|}
\hline \multirow{2}{*}{ No } & \multirow{2}{*}{ Negara Supplier } & \multicolumn{5}{|c|}{ Nilai: USD Juta } & \multirow{2}{*}{$\begin{array}{c}\text { Growth } \\
\text { '19/'18 (\%) }\end{array}$} & \multirow{2}{*}{$\begin{array}{c}\text { Trend } \\
\text { '15-'19 } \\
\text { (\%) } \\
\end{array}$} & \multirow{2}{*}{$\begin{array}{c}\text { Share } \\
2019(\%)\end{array}$} \\
\hline & & 2015 & 2016 & 2017 & 2018 & 2019 & & & \\
\hline \multicolumn{2}{|r|}{ Total Impor } & 169.968 & 129.796 & 126.759 & 135.211 & 144.335 & 6,7 & $-2,8$ & 100,0 \\
\hline 1 & China & 24.062 & 18.841 & 19.391 & 22.244 & 27.067 & 21,7 & 4,1 & 18,8 \\
\hline 2 & United States of America & 22.067 & 17.342 & 14.637 & 18.041 & 17.097 & $-5,2$ & $-4,6$ & 11,8 \\
\hline 3 & United Arab Emirates & 8.627 & 6.930 & 8.216 & 12.080 & 10.365 & $-14,2$ & 9,7 & 7,2 \\
\hline 4 & Germany & 11.825 & 8.181 & 7.135 & 7.292 & 7.004 & $-4,0$ & $-11,0$ & 4,9 \\
\hline 5 & Japan & 9.747 & 7.176 & 5.246 & 5.474 & 6.546 & 19,6 & $-10,1$ & 4,5 \\
\hline 6 & India & 5.885 & 4.932 & 5.132 & 5.685 & 6.489 & 14,1 & 3,4 & 4,5 \\
\hline 7 & France & 4.349 & 3.414 & 3.868 & 4.588 & 5.028 & 9,6 & 6,0 & 3,5 \\
\hline 8 & Italy & 5.139 & 4.231 & 4.307 & 4.236 & 4.310 & 1,7 & $-3,4$ & 3,0 \\
\hline 9 & Korea, Republic of & 9.683 & 5.873 & 4.974 & 4.300 & 4.027 & $-6,3$ & $-18,7$ & 2,8 \\
\hline \multirow[t]{2}{*}{10} & United Kingdom & 4.815 & 3.043 & 2.948 & 3.124 & 3.085 & $-1,3$ & $-8,3$ & 2,1 \\
\hline & Subtotal (10 Negara) & 106.198 & 79.963 & 75.854 & 87.065 & 91.018 & 4,5 & $-2,2$ & 63,1 \\
\hline \multirow[t]{2}{*}{16} & Indonesia & 2.446 & 1.489 & 1.566 & 1.578 & 2.163 & 37,1 & $-1,9$ & 1,5 \\
\hline & Lainnya & 61.324 & 48.344 & 49.339 & 46.569 & 51.154 & 9,8 & $-3,9$ & 35,4 \\
\hline
\end{tabular}

Sumber: Trade map (2020), diolah

Sementara impor Arab Saudi pada 2019 didominasi oleh Mesin-mesin / pesawat mekanik (HS 84), Kendaraan dan bagiannya (HS 87), Mesin/peralatan listrik (HS 85), Kapal laut (HS 89), dan Produk industri farmasi (HS 30). Impor ke 5 kelompok produk tersebut sudah mencapai USD 56,98 Triliun atau sebanyak 39,5\% dari total impor Arab Saudi pada 2019. Dari kelima kelompok produk utama HS 2 digit tersebut, hanya kapal laut dan produk industry famasi yang tidak dikenai perubahan tarif bea masuk. Sedangkan bea masuk untuk mesin- mesin / pesawat mekanik naik menjadi 7\%-15\%, Kendaraan dan bagiannya naik menjadi $7 \%$, dan mesin / peralatan listrik naik menjadi 15\% (Saudi Custom, 2020).

Berdasarkan data tarif dari Saudi Custom, terdapat sebanyak 37 kelompok produk impor Arab Saudi dari dunia (HS 2 digit) dikenai kenaikan tarif bea masuk. Nilai kelompok produk tersebut pada tahun 2019 mencapai USD 86,94 miliar atau sebesar 60,2\% dari total impor Arab Saudi.

Tabel 4. Perkembangan Impor Arab Saudi dari Dunia Berdasarkan Produk

\begin{tabular}{|c|c|c|c|c|c|c|c|c|c|c|}
\hline \multirow{2}{*}{ No } & \multirow{2}{*}{ HS } & \multirow{2}{*}{ Deskripsi } & \multicolumn{5}{|c|}{ Nilai: USD Juta } & \multirow{2}{*}{\begin{tabular}{|c|} 
Growth (\%) \\
$2019 / 2018$ \\
\end{tabular}} & \multirow{2}{*}{\begin{tabular}{|c|} 
Tren $(\%)$ \\
$2015-2019$ \\
\end{tabular}} & \multirow{2}{*}{$\begin{array}{c}\text { Share (\%) } \\
2019\end{array}$} \\
\hline & & & 2015 & 2016 & 2017 & 2018 & 2019 & & & \\
\hline & & Total Impor & 169.968 & 129.796 & 126.759 & 135.211 & 144.335 & 6,7 & $-2,8$ & 100,0 \\
\hline 1 & 851712 & $\begin{array}{l}\text { Telephones for cellular networks } \\
\text { "mobile telephones" or for other } \\
\text { wireless networks }\end{array}$ & 6.009 & 3.909 & 4.864 & 4.766 & 5.076 & 6,5 & $-1,4$ & 3,5 \\
\hline 2 & 870322 & $\begin{array}{l}\text { Motor cars and other motor vehicles } \\
\text { principally designed for the transport of } \\
\text { persons }\end{array}$ & 866 & 527 & 496 & 1.184 & 5.034 & 325,1 & 54,2 & 3,5 \\
\hline 3 & "870321 & $\begin{array}{l}\text { Motor cars and other motor vehicles } \\
\text { principally designed for the transport of } \\
\text { persons }\end{array}$ & 1.274 & 746 & 881 & 2.077 & 4.751 & 128,8 & 44,1 & 3,3 \\
\hline 4 & 271012 & $\begin{array}{l}\text { Light oils and preparations, of } \\
\text { petroleum or bituminous minerals } \\
\text { which }>=90 \% \text { by volume }\end{array}$ & 325 & 198 & 2.224 & 3.422 & 3.260 & $-4,7$ & 110,8 & 2,3 \\
\hline 5 & 300490 & $\begin{array}{l}\text { Medicaments consisting of mixed or } \\
\text { unmixed products for therapeutic or } \\
\text { prophylactic purposes }\end{array}$ & 2.364 & 2.676 & 2.941 & 3.158 & 2.935 & $-7,1$ & 6,2 & 2,0 \\
\hline 6 & "880330 & $\begin{array}{l}\text { Parts of aeroplanes or helicopters, } \\
\text { n.e.s. (excluding those for gliders) }\end{array}$ & 2.743 & 2.398 & 2.139 & 2.320 & 2.490 & 7,3 & $-2,2$ & 1,7 \\
\hline 7 & フ10812 & $\begin{array}{l}\text { Gold, incl. gold plated with platinum, } \\
\text { unwrought, for non-monetary purposes } \\
\text { (excluding gold) }\end{array}$ & 5.085 & 2.163 & 2.548 & 3.138 & 2.331 & $-25,7$ & $-11,2$ & 1,6 \\
\hline 8 & 890590 & $\begin{array}{l}\text { Light-vessels, fire-floats, floating } \\
\text { cranes and other vessels }\end{array}$ & 15 & 4 & 50 & 779 & 1.812 & 132,6 & 339,0 & 1,3 \\
\hline 9 & 851762 & $\begin{array}{l}\text { Machines for the reception, conversion } \\
\text { and transmission or regeneration of } \\
\text { voice }\end{array}$ & 1.083 & 740 & 1.115 & 1.083 & 1.801 & 66,2 & 15,0 & 1,2 \\
\hline 10 & 890520 & $\begin{array}{l}\text { Floating or submersible drilling or } \\
\text { production platforms }\end{array}$ & 313 & 290 & 400 & 1.590 & 1.453 & $-8,6$ & 61,2 & 1,0 \\
\hline & Lainnya & & 149.892 & 116.144 & 109.103 & 111.694 & 113.394 & 1,5 & $-5,8$ & 78,6 \\
\hline
\end{tabular}


Sumber: Trade map (2020), diolah

\section{Perkembangan Perdagangan Indonesia dengan Arab Saudi}

Arab Saudi merupakan mitra dagang utama Indonesia yang menempati urutan ke 20. Total nilai ekspor non migas Indonesia ke Arab Saudi pada tahun 2019 adalah sebesar USD 1,502 miliar atau tumbuh 22,9\% dibanding tahun 2018. Selama Januari-Oktober 2020, nilai ekspor non migas Indonesia tercatat USD 1,083 miliar atau turun $13,5 \%$ dibanding periode yang sama tahun sebelumnya yang mecapai USD 1,252 miliar. Pangsa ekspor Indonesia ke Arab saudi pada tahun 2019 adalah sebesar 0,92\% dari total nilai eskpor Indonesia ke dunia (Trade map, 2020).
Berdasarkan data statistic perdagangan, total nilai ekspor Indonesia ke Arab Saudi pada tahun 2019 adalah sebesar USD 1,503 miliar yang terdiri dari ekspor migas sebesar USD 0,17 juta dan ekspor non migas sebesar USD 1,503 miliar.

Sementara total nilai impor Indonesia dari Arab Saudi tercatatsebesar USD 3,5 miliar yang terdiri dari impor migas sebesar USD 2,8 miliar dan impor non migas sebesar USD 733 juta. Neraca perdagangan Indonesia dengan Arab Saudi pada tahun 2019 tercatat deficit sebesar USD 2,06 miliar.

Tabel 5. Perkembangan Perdagangan Indonesia dengan Arab Saudi

\begin{tabular}{|c|c|c|c|c|c|c|c|c|c|}
\hline \multirow{3}{*}{ URAIAN } & \multicolumn{7}{|c|}{ NILAI : USD Juta } & \multirow{3}{*}{\begin{tabular}{|c|} 
PERUBAHAN (\%) \\
$20 / 19$
\end{tabular}} & \multirow{3}{*}{\begin{tabular}{|c|} 
TREND (\%) \\
$15-19$ \\
\end{tabular}} \\
\hline & \multirow{2}{*}{2015} & \multirow{2}{*}{2016} & \multirow{2}{*}{2017} & \multirow{2}{*}{2018} & \multirow{2}{*}{2019} & \multicolumn{2}{|c|}{ JANUARI - OKTOBER } & & \\
\hline & & & & & & 2019 & 2020 & & \\
\hline Ekspor & 2.061 & 1.333 & 1.378 & 1.222 & 1.503 & 1.252 & 1.083 & $-13,50$ & $-6,92$ \\
\hline - Migas & - & - & 0 & 0 & 0 & 0 & 0 & $-71,45$ & 0,00 \\
\hline - Non Migas & 2.061 & 1.333 & 1.378 & 1.222 & 1.503 & 1.252 & 1.083 & $-13,50$ & $-6,93$ \\
\hline Impor & 3.422 & 2.725 & 3.167 & 4.911 & 3.568 & 2.916 & 2.103 & $-27,90$ & 6,96 \\
\hline - Migas & 2.749 & 2.020 & 2.359 & 3.651 & 2.834 & 2.277 & 1.707 & $-25,03$ & 6,75 \\
\hline - Non Migas & 673 & 706 & 808 & 1.259 & 734 & 639 & 395 & $-38,14$ & 7,81 \\
\hline Total Perdagangan & 5.482 & 4.058 & 4.545 & 6.133 & 5.071 & 4.169 & 3.186 & $-23,58$ & 2,60 \\
\hline - Migas & 2.749 & 2.020 & 2.359 & 3.652 & 2.834 & 2.277 & 1.707 & $-25,03$ & 6,75 \\
\hline - Non Migas & 2.734 & 2.039 & 2.186 & 2.482 & 2.237 & 1.891 & 1.479 & $-21,82$ & $-2,03$ \\
\hline Neraca & 1.361 & 1.392 & 1.789 & 3.688 & 2.065 & 1.664 & 1.019 & $-38,74$ & \\
\hline - Migas & 2.749 & 2.020 & 2.359 & 3.651 & 2.834 & 2.277 & 1.707 & $-25,03$ & \\
\hline - Non Migas & 1.388 & 628 & 570 & 37 & 769 & 613 & 688 & 12,17 & $-10,34$ \\
\hline
\end{tabular}

Sumber: BPS (2020), diolah

Namun tren impor selama periode 2015-2019 justru mengalami pertumbuhan positif sebesar 6,96\% per tahunnya. Dengan pertumbuhan laju impor yang jauh lebih tinggi dibandingkan ekspor, Indonesia mengalami defisitneraca perdagangan selama periode tersebut. Nilai defisit neraca perdagangan terbesar Indonesia dengan Arab Saudi selama lima tahun terakhir adalah pada tahun 2018 yakni sebesar USD 3,688 miliar.

Berdasarkan HS 2 digit, produk ekspor Indonesia ke Arab Saudi yang tertinggi adalahKendaraan dan bagiannya (HS 87) dengannilai ekspor tercatat sebesar USD 464 juta atausebesar 30,87\% dari total ekspor non migas Indonesia (Trade map,2020).

Produk ekspor utama lainnya adalah Minyak hewan dan nabati (HS 15) dengan nilai USD 227 juta $(15,10 \%)$ disusul Kayu dan produkkayu (HS 44) senilai USD 122,8 juta $(8,18 \%)$; Produk kertas (HS 48) senilai USD 106,2 juta (7,07\%); Produk olahan daging dan ikan (HS 16) senilai USD 67,1 juta $(4,46 \%)$. Aneka makanan olahan (HS 21) senilai USD 60 juta (3,99\%); Karet dan Produk olahannya (HS 40) senilai USD 56,5 juta $(3,76 \%)$; Kain dan benang (HS 54) senilai 48,5 juta (3,23\%); benda-benda dari besi dan baja (HS 73) senilai USD 42,2 juta (2,81\%); dan Snack dan pasta (HS 19) senilai USD 29,7 (1,98\%). Total 
nilai ekspor kesepuluhproduk ini mencapai $81,5 \%$ dari total eksporkeseluruhan.

Pada tahun 2019, produk utama ekspor non migas (HS 8 digit) Indonesia ke Arab Saudi adalah kendaraan bermotor lainnya

\section{Dampak Kenaikan Tarif Bea Masuk terhadap Kinerja Ekspor Produk Indonesia}

Berdasarkan data tarif dari Custom Saudi, teridentifikasi bahwa terdapat sebanyak 37 pos tarif (HS 2 digit) yang mengalami kenaikan tarif. Namun demikian, jika dilihat lebih detail, tidak seluruh produk dalam kategori HS 8 digitdalam 37 pos tarif tersebut mengalami kenaikan. Hanya terdapat 568 pos tarif (HS 8 digit) yang mengalami kenaikan.

Di level HS 8 digit, teridentifikasi bahwa dari total produk ekspor non migas Indonesia ke Arab Saudi yang berjumlah 2198 postarif, hanya 67 pos tarif produk Indonesia yang mengalami perubahan kenaikan tarif dengan kisaran kenaikan menjadi 6 - $20 \%$ dari yang semula 5$12 \%$. Sementara sejumlah 2131 pos tarif atau sebanyak $97,49 \%$ tidak mengalami kenaikantarif.

Total nilai ekspor non migas Indonesia di tahun 2019 untuk produk yang mengalami kenaikantarif adalah USD 37,64 juta atau sebesar 2,5\% dari total nilai ekspor keseluruhan Indonesia ke Arab Saudi (BPS dan Custom Saudi, 2020).

Produk ekspor Indonesia yang berpotensi terdampak kinerja ekspornya karena mengalami kenaikan tarif bea masuk adalah sebagai berikut dengan masing-masing pangsanya: produk dari besi dan baja (HS 73; $1,54 \%$ ), besi dan baja (HS 72; 0,79\%), serat staple buatan (HS 55;0,06\%), mesin-mesin / pesawat mekanik (HS 84;0,05\%), dan produk kertas(HS $48 ; 0,04 \%)$.

Sementara produk ekspor utama Indonesia ke Arab Saudi yang tidak mengalami kenaikan yaknidengan kode HS 87032368 dengan pangsa 11,9\%, HS 87032365 (11,5\%), dan HS $87032259(2,9 \%)$ disusul turunan CPO HS 15119049 (9,6\%); Tuna HS 16041411 (4,4\%) Ban HS 40111000 (3,7\%); Bumbu HS 21039019 (3,3\%); serta produk Kertas HS 48025641 (2,6\%).

tarif adalah minyak hewan dan nabati (HS 15), produk kayu (HS 44), produk daging dan Ikan olahan (HS 16), bahan makanan (HS 21), produk karet (HS 40), kain dan benang (HS 54), serta snack dan pasta (HS 19). Meskipun terdapat beberapa produk Indonesia terdampak kenaikan tarif namun secara agregat tidak berdampak pada kinerja ekspor produk utama Indonesia tersebut.

\section{A. Dampak Kenaikan Tarif Bea Masuk terhadap Kinerja Produk Utama Ekspor Indonesia}

Berikut adalah analisis potensi dampak kenaikan tarif bea masuk terhadap kinerja eksporproduk utama Indonesia ke Arab Saudi kategori HS 2digit:

a. Kendaraan dan Bagiannya (HS 87)

Total nilai ekspor Indonesia untuk produk kendaraan dan bagiannya (HS 87)di tahun 2019 adalah sebesar USD 464 juta. Selama Januari-Oktober 2020 nilai ekspornya tercatat sebesar USD 344 juta atau turun 5,23\% disbanding tahun sebelumnya. Sementara tren ekspornya selama 2015-2019 adalah -14,06\%.

Produk ekspor utama Indonesia untuk HS 87 ini adalah Mobil penumpang (HS 87032368) senilai USD 178,2 juta dan pangsa 11,9\% kemudian disusul HS 87032365 senilai USD 172,2 juta (11,5\%), HS 87032259 senilai 43,07 juta $(2,9 \%)$, dan HS 87032367 senilai USD 32,72 juta $(2,2 \%)$ (BPS, 2020).

Berdasarkan data Custom Saudi, produk dalam klasifikasi HS 87 yang mengalami kenaikantarif menjadi $7 \%$ dari yang semula $5 \%$ hanyaterdiri dari 2 pos tarif yakni HS 87021000 (with only compression-ignition internal combustion piston engine...) dan HS 87029000 (other). Untuk kedua pos tarif tersebut, Indonesia 
tidaktercatat melakukan ekspor ke Arab Saudi. Hal ini berarti bahwa untuk produk HS 87 yang saat ini diekspor dari Indonesia ke Arab Saudi tidakterdampak akibat kenaikan tarif tersebut.

Tabel 6. Nilai Ekspor dan Perubahan Tarif untuk Produk Kendaraan dan Bagiannya (HS 87)

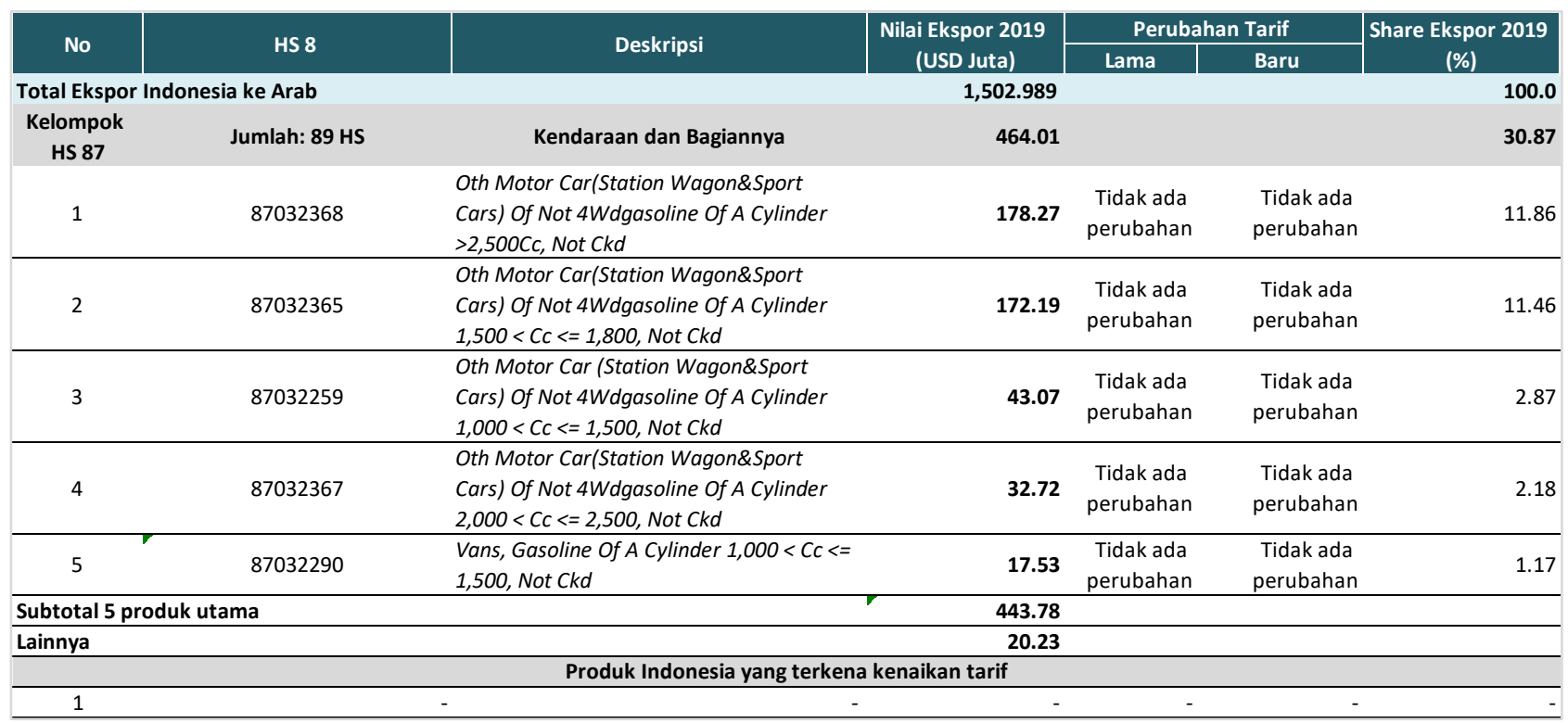

Sumber: Custom Saudi dan BPS (2020), diolah

b. Produk Kertas (HS 48)

Total nilai ekspor Indonesia untuk produk kertas (HS 48) di tahun 2019 mencapai USD 106,22 juta. Sementara selama Januari-Oktober 2020 ekspornya tercatat USD 71,07 juta atau turun $20,25 \%$ jika dibanding periode yang sama tahun sebelumnya. Tren ekspornya selama 2015-2019 juga turun dengan laju penurunan rata-rata sebesar $4,64 \%$ per tahunnya (BPS, 2020).

Produk utama yang diekspor adalah Other paper and paperboard...width $<36$ (HS 48025641 ) senilai USD 38,35 juta dan pangsa $2,6 \%$ kemudian Other paper and paperboard... oththn multiply paper (HS 48025690) senilai USD 11,69 juta (0,8\%), Toilet / Facial tissue (HS 48030090) senilai USD 10,9 juta $(0,7 \%)$, Other Uncoated Paper (HS 48059190) senilai USD 7,05 juta (0,5\%), dan Register, Account Books, Note Books (HS 48201000) senilai USD 6,7 Juta $(0,5 \%)(B P S, 2020)$.
Ekspor Produk Kertas / Karton Indonesia ke Arab Saudi terdiri dari 65 pos tarif di level HS 8 digitnya. Namun, hanya 5 HS saja yang dikenai kenaikan tarif bea masuk. Produk tersebutmengalami kenaikan tarif menjadi 8$10 \%$ dari yang semula 5\%. Tiga HS 8 digitter dampakdengan nilai eksporter besar yaitu Felt Paper and Paperboard (HS 48055000), Trays, Dishes, Plates, Cups and The Like (HS 48236900), dan Other Kraft Paper (HS 48239099). Total ketigaproduk tersebut mencapai100 \% dari total ekspor produk kertas yang dikenaikenaikan tarif.

Pada tahun 2019, nilai ekspor produk-produk tersebut sebesar USD 0,58 Juta atau 0,04\% dari total ekspor Indonesia ke Arab Saudi. Jika dilihat dari besaran kenaikan tarif yakni kisaran 3-5\%, maka diperkirakan bahwa produk kertas Indonesia cukup terdampak akibat kenaikantarif tersebut dan berpotensi mengalami penurunan ekspor. 


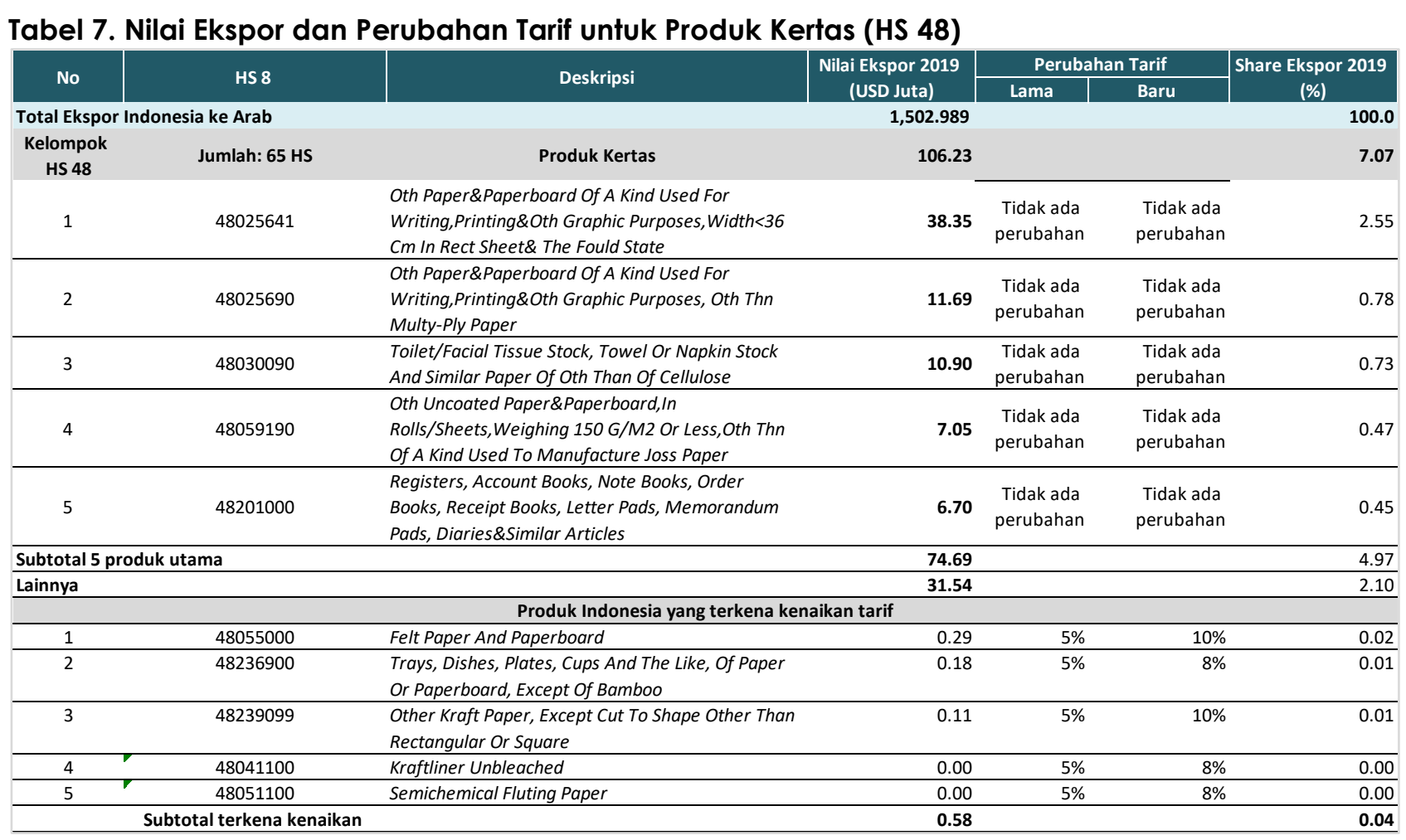

Sumber: Custom Saudi dan BPS (2020), diolah

\section{Benda-benda dari Besi dan Baja (HS 73)}

Total nilai ekspornya pada tahun 2019 adalah USD 42,26 juta. Nilai ekspor selama JanuariOktober 2020 adalah senilai USD 25,8 juta atauturun $36,01 \%$ dibanding tahun sebelumnya. Meskipun pertumbuhan selama Januari-Oktober 2020 turun, namun untuk tren selama 2015-2019 masih tumbuh dengan laju pertumbuhan rata-rata per tahun sebesar 3,77\% (BPS, 2020).

Produk benda-benda dari besi dan baja utama yang diekspor Indonesia ke Arab Saudi yaitu line pipe used for oil/gas (HS 73041900) senilai USD 22,84 Juta (1,52\%), tableware/oth household article (HS 73239390) senilai USD 7,34 Juta $(0,49 \%)$, other butt-welding fitting (HS $73072390)$ senilai USD 3,97 Juta $(0,26 \%)$, oth tube or pipe fitting diameter $>=15 \mathrm{~cm}$ (HS 73079190) senilai USD 1,85 Juta $(0,12 \%)$, dan oth tube/pipe fitting threshold (HS 730790) senilai USD 1,69 Juta $(0,11 \%)$ (BPS, 2020).
Ekspor poduk dari besi dan baja ke Arab Saudi terdiri dari 77 produk (HS 8 digit), dimana 10 HS (senilai USD 23,19 Juta) termasuk dalam HS yang dikenai kenaikan bea masuk impor Arab Saudi. Tiga HS 8 digit terdampak dengan nilai ekspor terbesar yaitu Line Pipe Used for Oil/Gas Pipelines Oth of Stainless Steel (HS 73041900), Cigarette Cases and Boxes Not of Iron or Steel (HS 73269099), dan Welded Angles, Shapes and Sections of Iron or Steel (HS 73012000). Pada tahun 2019, nilai ekspor produk-produk tersebut sebesar USD 23,19 Juta atau 1,54\% dari total ekspor Indonesia ke Arab Saudi. Sementara, prosentase produk tersebut terhadap sektor di HS 73 cukup besar yakni sebesar $54,87 \%$.

Tarif baru untuk produk HS 73 ini ada pada kisaran $8-15 \%$ dari yang semula 5\%. Hal iniberarti besaran kenaikan tarif adalah antara $3-10 \%$. Jika dilihat besarannya, kenaikan ini cukup besar sehingga diperkirakan kenaikan tarif untuk produk kategori ini akan menurunkan dayasaing produk Indonesia. 


\begin{tabular}{|c|c|c|c|c|c|c|}
\hline \multirow{2}{*}{ No } & \multirow{2}{*}{ HS 8} & \multirow{2}{*}{ Deskripsi } & \multirow{2}{*}{$\begin{array}{l}\text { Nilai Ekspor } 2019 \\
\text { (USD Juta) }\end{array}$} & \multicolumn{2}{|c|}{ Perubahan Tarif } & \multirow{2}{*}{$\begin{array}{c}\text { Share Ekspor } \\
2019(\%)\end{array}$} \\
\hline & & & & Lama & Baru & \\
\hline \multicolumn{3}{|c|}{ Total Ekspor Indonesia ke Arab } & $1,502.989$ & & & 100.0 \\
\hline $\begin{array}{l}\text { Kelompok } \\
\text { HS } 73\end{array}$ & 77 HS & Benda-benda dari Besi dan Baja & 42.26 & & & 2.81 \\
\hline 1 & 73041900 & Line Pipe Used For Oil/Gas Pipelines Oth Of Stainless Steel & 22.84 & $5 \%$ & $10 \%$ & 1.52 \\
\hline 2 & 73239390 & Tableware/Oth Household Articles And Parts Thereof, Of Stainless Steel & 7.34 & $\begin{array}{c}\text { Tidak ada } \\
\text { perubahan }\end{array}$ & $\begin{array}{c}\text { Tidak ada } \\
\text { perubahan }\end{array}$ & 0.49 \\
\hline 3 & 73072390 & Other Butt Welding Fittings, Having An Internal Diameter Of Less Than $15 \mathrm{Cm}$ & 3.97 & $\begin{array}{c}\text { Tidak ada } \\
\text { perubahan }\end{array}$ & $\begin{array}{c}\text { Tidak ada } \\
\text { perubahan }\end{array}$ & 0.26 \\
\hline 4 & 73079190 & Oth Tube Or Pipe Fittings Flanges, Internal Diameter $>=15 \mathrm{Cm}$ & 1.85 & $\begin{array}{c}\text { Tidak ada } \\
\text { perubahan }\end{array}$ & $\begin{array}{l}\text { Tidak ada } \\
\text { perubahan }\end{array}$ & 0.12 \\
\hline 5 & 73079290 & $\begin{array}{l}\text { Oth Tube/Pipe Fittings Threaded Elbows, Bends\&Sleeves, Internal } \\
\text { Diameter }>=15 \mathrm{Cm}\end{array}$ & 1.69 & $\begin{array}{c}\text { Tidak ada } \\
\text { perubahan }\end{array}$ & $\begin{array}{c}\text { Tidak ada } \\
\text { perubahan }\end{array}$ & 0.11 \\
\hline \multicolumn{3}{|c|}{ Subtotal 5 produk utama } & 37.69 & & & 2.51 \\
\hline \multicolumn{3}{|l|}{ Lainnya } & 4.57 & & & 0.30 \\
\hline \multicolumn{7}{|c|}{ Produk Indonesia yang terkena kenaikan tarif } \\
\hline 1 & 73041900 & Line Pipe Used For Oil/Gas Pipelines Oth Of Stainless Steel & 22.84 & $5 \%$ & $10 \%$ & 1.52 \\
\hline 2 & 73269099 & Cigarette Cases And Boxes, Not Of Iron Or Steel & 0.35 & $5 \%$ & $15 \%$ & 0.02 \\
\hline 3 & 73012000 & Welded Angles, Shapes And Sections Of Iron Or Steel & 0.00 & $5 \%$ & $10 \%$ & 0.00 \\
\hline 4 & 73071900 & Other Cast Fittings Of Non-Malleable Cast Iron & 0.00 & $5 \%$ & $10 \%$ & 0.00 \\
\hline \multirow[t]{2}{*}{5} & 73089020 & Other Prefabricated Modular Type Joinedby Shear Connectors & 0.00 & $5 \%$ & $10 \%$ & 0.00 \\
\hline & & Other Manhole Covers, Gratings And Frames There For Not Of Non- & & & & \\
\hline \multirow[t]{2}{*}{6} & 73259990 & Malleable Cast Iron & 0 & $5 \%$ & $10 \%$ & 0.00 \\
\hline & & Stainless Steel Clamp Assemblies With Rubber Sleeves Used For Hubless & & & & \\
\hline 7 & 73269030 & Cast Iron Pipes And Pipe Fittings & 0 & $5 \%$ & $10 \%$ & 0.00 \\
\hline \multirow[t]{2}{*}{8} & 73021000 & Rails For Railway/Tramway Track Construction Material Ofiron/Steel & 0 & $5 \%$ & $12 \%$ & 0.00 \\
\hline & & Sheet Piling Of Iron/Steel,Whether/Not Drill,Punched/Madefrom Assembled & & & & \\
\hline \multirow[t]{2}{*}{9} & 73011000 & Elements & 0 & $5 \%$ & $15 \%$ & 0.00 \\
\hline & & Casing And Tubing Of A Kind Used In Drilling For Oil/Gas Welded, Of & & & & \\
\hline 10 & 73062100 & Stainless Steel & 0 & $5 \%$ & $15 \%$ & 0.00 \\
\hline \multicolumn{3}{|c|}{ Subtotal terkena kenaikan } & 23.19 & & & 1.54 \\
\hline
\end{tabular}

Sumber: Custom Saudi dan BPS (2020), diolah

\section{d. Produk Plastik (HS 39)}

Total nilai ekspornya pada tahun 2019 adalahsebesar USD 28,53 juta. Selama JanuariOktober 2020 nilai ekspornya sebesar USD 23,36 juta atau turun $1,9 \%$ jika dibandingkan periode yang sama tahun sebelumnya. Namun demikian tren selama periode 2015-2019 masih positif yakni dengan laju pertumbuhan sebesar $0,51 \%$ per tahun.

Produk yang dominan diekspor dari kelompok HS 39 ini adalah Foil and Strip (HS 39211999) yakni dengan nilai dan pangsa sebesar USD 17,59 juta $(1,2 \%)$ disusul Other Household articles (HS 39249090) senilai USD 3,03 juta (0,2\%), dan Plates and Sheets (HS 39201019) senilai USD 1,73 juta $(0,1 \%)$ (BPS, 2020).
Produk plastik ini mengalami kenaikan tarifmenjadi $7 \%$ dari yang semula $5 \%$. Ekspor produk Plastik dan Barang dari Plastik ke Arab Saudi terdiri dari 72 produk (HS 8 digit), dimana 3 HS termasuk dalam HS yang dikenai kenaikan bea masuk impor Arab Saudi. Tiga HS 8 digitterdampak yaitu Polyurethanes (HS 39095000), Cellulose Ethers, Carboxymethylcellulose \& Its Salts (HS $39123100)$, dan Waste, Parings \& Scrap, Of Oth Plastics(HS 39159000). Namundemikian selama 4 tahun terakhir Indonesia tercatat tidak melakukan ekspor untuk produk-produk tersebut. Sehingga kenaikan tarif untuk produk - produk tersebut dianggap tidak akan memberikan dampak bagi perdagangan Indonesia ke Arab Saudi. 


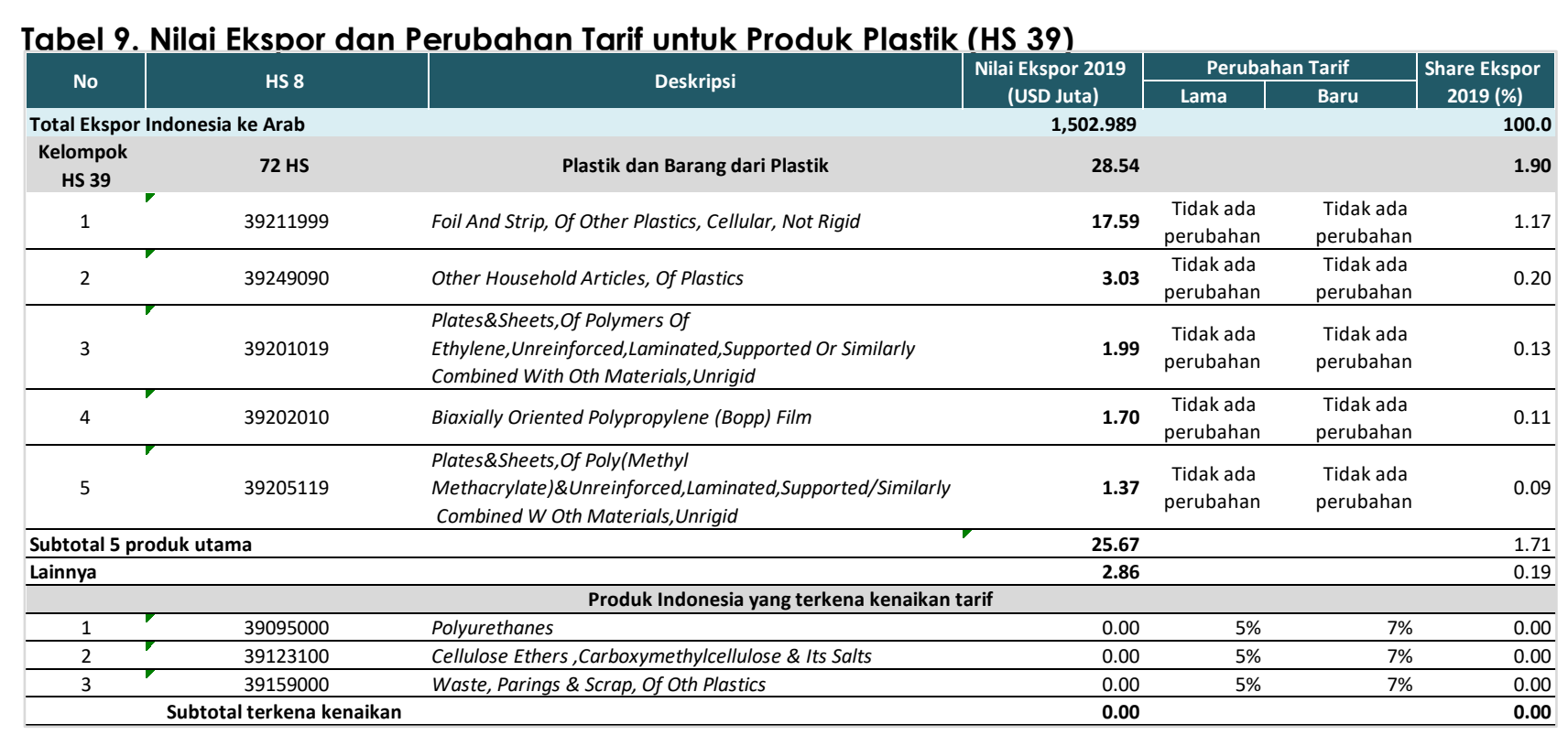

Sumber: Custom Saudi dan BPS (2020), diolah

\section{e. Produk Elektronik (HS 85)}

Total nilai ekspornya pada tahun 2019 adalahsebesar USD 22,98 juta. Selama JanuariOktober 2020 nilai ekspornya sebesar USD 22,5 juta atau naik 16,39\% dibanding periode yang sama tahun sebelumnya. Meskipun selama tahun 2020 (Januari-Oktober) ekspornya tumbuh, namun tren ekspor produk elektronik selama tahun 2015-2019 mengalami penurunandengan laju penurunan sebesar 0,59\% per tahun (BPS, 2020).

Produk yang dominan diekspor dari kelompok HS 85 ini adalah Lead-Acid Accumulator (HS 85071099) dengan nilai ekspor sebesar USD 15,3 juta dan pangsa 1,01\%, kemudian Battery separators (HS 85079092) dengan nilai USD 1,29 juta (0,08\%); dan Primary battery (HS 85061010) senilai USD 1,21 juta (0,08\%).

Produk elektronik ini mengalami kenaikan tarif menjadi $15 \%$ dari yang semula $5-12 \%$. Hal ini berarti rentang kenaikan tarif tertinggi adalahsebesar $10 \%$. Total produk ekspor Indonesia untuk HS 85 ini berjumlah 167 pos tarif (HS 8 digit) dimana tidak ada satu pun yang terkenakenaikan tarif. Meskipun nilai dan pangsa ekspor Indonesia untuk HS 85 ini relatif kecil di pasar Arab Saudi, namun dengan tidak adanya produk ekspor Indonesia yang mengalami kenaikan tarif maka dapat dikatakan bahwa ekspor Indonesia untuk HS 85 ini tidak akan terpengaruh.

\section{Tabel 10. Nilai Ekspor dan Perubahan Tarif untuk Produk Elektronik (HS 85)}




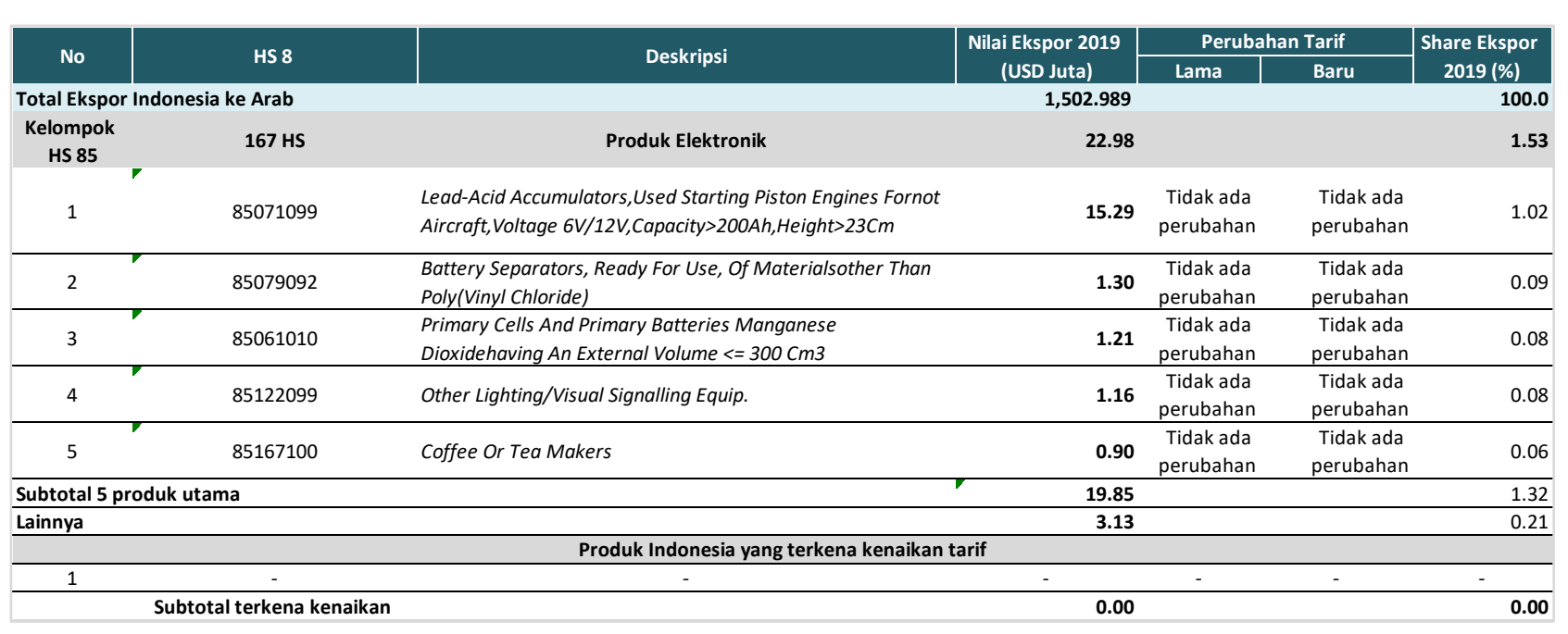

Sumber: Custom Saudi dan BPS (2020), diolah

\section{B. Dampak Kenaikan Tarif Bea Masuk terhadap Kinerja Produk Ekspor Indonesia Lainnya}

Berikut adalah analisis beberapa produk ekspor Indonesia ke Arab Saudi dalam kategori HS 2 digit diluar 'produk utama yang akan terdampak besar oleh kenaikan bea masuk diantaranya yaitu:

\section{a. Besi dan Baja (HS 72)}

Total nilai ekspornya pada tahun 2019 adalah USD 12,04 juta. Nilai ekspor selama JanuariOktober 2020 mencapai USD 4,42 juta atau turun $61,92 \%$ dibandingkan periode yang sama tahun sebelumnya. Hal ini sejalan dengantren selama periode 2015-2019 tumbuh negatifsebesar 27,40\% per tahun (BPS, 2020).

Besi dan baja mengalami kenaikan tarif menjadi $12 \%-15 \%$ dari semula $5 \%$. Indonesia mengekspor 17 pos tarif (HS 8 digit) pada kelompok besi dan baja, dimana $10 \mathrm{HS}$ senilai USD 1 1,84 juta dikenai kenaikan tarif bea masuk. Tiga pos tarif (HS 8 digit) yang akan terdampak berat yaitu Iron/Non-Alloy Steel Not in Coils (HS 72085100), Iron/Non-Alloy Steel Not In Coils (HS 72085200), dan Stainless Steel In Ingots/Other Primary Form (HS 72181000). Pangsa produklron/Non-Alloy Steel Not In Coils (HS 72085100) terhadap total ekspor besi dan baja mencapai $93,6 \%$. Kenaikan tarif untuk produk ini akansangat mempengaruhi kinerja ekspor besi dan baja Indonesia ke Arab Saudi.

Dari sisi Arab Saudi, menurut Conn dan Codbouly (2020), kenaikan tarif impor besi dan baja ini dapat berdampak pada investasi terutama terkait proyek pembangunan infrastruktur. Dampak yang ditimbulkan tidak hanya dikarenakan kenaikan tarif bea masuk melainkan juga dampak akibat diberlakukannya penerapan kenaikan value added tax (VAT) dari yang awalnya 5\% (diterapkan sejak 1 Januari 2018) menjadi 15\% atau naik 3 kali lipat dan mulai diberlakukan sejak 1 Juli 2020. Kebijakan ini tentu akan berdampak signifikan terhadapproyek pembangunan terutama yang dilakukan melalui skema public private partnership (PPP). 
Tabel 11. Nilai Ekspor dan Perubahan Tarif untuk Besi dan Baja (HS 72)

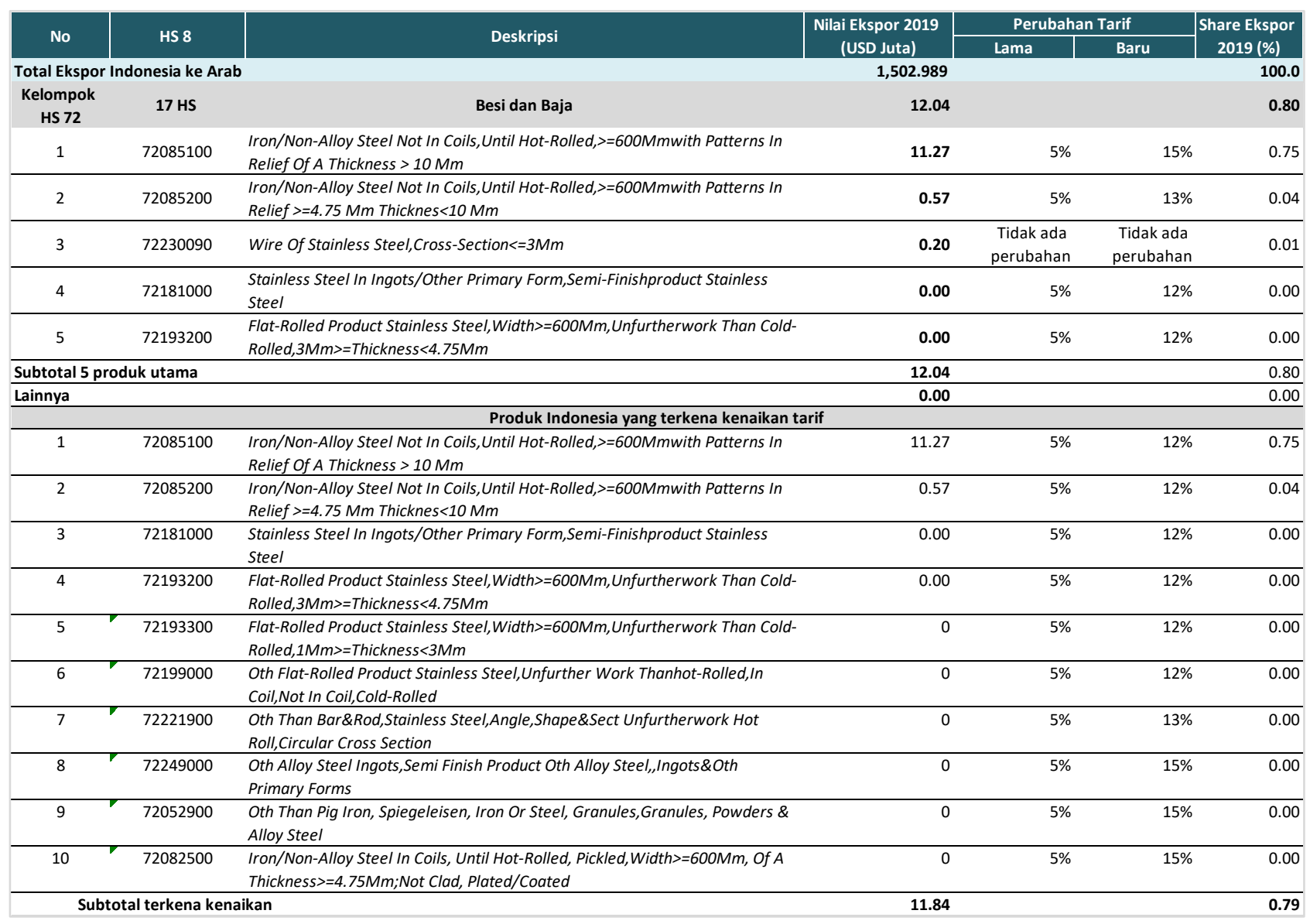

Sumber: Custom Saudi dan BPS (2020), diolah

b. Serat Stapel Buatan (HS 55)

Total nilai ekspornya pada tahun 2019 adalah USD 12,97 juta. Nilai ekspor selama JanuariOktober 2020 mencapai USD 11,45 juta atau turun $1,09 \%$ dibandingkan periode yang samatahun sebelumnya. Namun demikian tren selama periode 2015-2019 masih positif yaknidengan laju pertumbuhan sebesar 6,89\% per tahun.

Produk serat staple buatan mengalami kenaikan tarif menjadi $15 \%$ dari sebelumnya
12\%. Pada 2019, Indonesia mengekspor 28 pos tarif (HS 8 digit) senilai USD 12,97 Juta pada kelompok serat staple buatan, di mana hanya 2 pos tarif (HS 8 digit) pada kelompok ini yang dikenai kenaikan tarif bea masuk, yaitu Fibres, Synthetic Staple Fibres, Of Polyesters (HS 55032000) dan Containing $85 \%$ Or More by Weight of Polyester Staple Fibres (HS 55121100). Ekspor kedua HS ini sebesar USD 0,8 juta. Meskipun nilai ekspornya terbilang kecil $(6,2 \%)$, namun kenaikan tarif untuk produk ini akan turut mempengaruhi kinerja ekspor produk tersebut ke Arab Saudi. 


\section{Tabel 12. Nilai Ekspor dan Perubahan Tarif untuk Serat Stapel Buatan (HS 55)}

\begin{tabular}{|c|c|c|c|c|c|c|}
\hline \multirow{2}{*}{ No } & \multirow{2}{*}{ HS 8} & \multirow{2}{*}{ Deskripsi } & \multirow{2}{*}{$\begin{array}{l}\text { Nilai Ekspor } 2019 \\
\text { (USD Juta) }\end{array}$} & \multicolumn{2}{|c|}{ Perubahan Tarif } & \multirow{2}{*}{$\begin{array}{c}\text { Share Ekspor } \\
2019(\%)\end{array}$} \\
\hline & & & & Lama & Baru & \\
\hline \multicolumn{3}{|c|}{ Total Ekspor Indonesia ke Arab } & $1,502.989$ & & & 100.0 \\
\hline $\begin{array}{l}\text { Kelompok } \\
\text { HS } 55\end{array}$ & 28 HS & Serat Stapel Buatan & 12.97 & & & 0.86 \\
\hline 1 & 55151100 & $\begin{array}{l}\text { Mixed Mainly Or Solely With Viscose Rayon Staple Fibres Of Polyester Staple } \\
\text { Fibres }\end{array}$ & 5.56 & $\begin{array}{c}\text { Tidak ada } \\
\text { perubahan }\end{array}$ & $\begin{array}{c}\text { Tidak ada } \\
\text { perubahan }\end{array}$ & 0.37 \\
\hline 2 & 55131100 & Unbleached Or Bleached Of Polyester Staple Fibres, Plain Weave & 2.28 & $\begin{array}{l}\text { Tidak ada } \\
\text { perubahan }\end{array}$ & $\begin{array}{l}\text { Tidak ada } \\
\text { perubahan }\end{array}$ & 0.15 \\
\hline 4 & 55151200 & Mixed Mainly Or Solely With Manmade Filaments Of Polyester Staple Fibres & 1.48 & $\begin{array}{c}\text { Tidak ada } \\
\text { perubahan }\end{array}$ & $\begin{array}{c}\text { Tidak ada } \\
\text { perubahan }\end{array}$ & 0.10 \\
\hline 5 & 55032000 & $\begin{array}{l}\text { Fibres, Synthetic Staple Fibres, Of Polyesters, Not Carded, Combed Or } \\
\text { Otherwise Processed For Spinning }\end{array}$ & 0.70 & $12 \%$ & $15 \%$ & 0.05 \\
\hline \multicolumn{3}{|c|}{ Subtotal 5 produk utama } & 11.60 & & & 0.77 \\
\hline \multicolumn{3}{|l|}{ Lainnya } & 1.37 & & & 0.09 \\
\hline \multicolumn{7}{|c|}{ Produk Indonesia yang terkena kenaikan tarif } \\
\hline \multicolumn{3}{|c|}{ Subtotal terkena kenaikan } & 0.83 & & & 0.06 \\
\hline
\end{tabular}

Sumber: Custom Saudi dan BPS (2020), diolah

\section{Mesin dan Peralatan Mesin(HS 84)}

Total nilai ekspornya pada tahun 2019 adalah USD 18,51 juta. Nilai ekspor selama JanuariOktober 2020 mencapai USD 14,31 juta atau turun $12,96 \%$ dibandingkan periode yang sama tahun sebelumnya. Hal ini sejalan dengan tren selama periode 2015-2019 tumbuh negatif sebesar 24,45\% per tahun. Produk Mesin dan Peralatan Mesin mengalami kenaikan tarifmenjadi berkisar $7 \%-15 \%$ dari semula $5 \%$ 12\%. Indonesia mengekspor 249 pos tarif (HS 8 digit) senilai USD 18,51 Juta pada kelompok mesin / pesawat mekanik, dimana 7 pos tarif
(HS 8 digit) senilai USD 0,76 juta dikenai kenaikanbea masuk. Tiga pos tarif (HS 8 digit) yang akan terdampak berat yaitu Refrigerating/Freezing Equipment (HS 84186990), Parts of Evaporators or Condensers (HS 84189910), dan Flywheels and pulleys (HS 84835000). Pangsa ekspor Refrigerating/freezing equipment (HS 84186990) cukup besar yaitu $3,41 \%$ dari total ekspor kelompok HS 84 atau menempati posisi terbesar ke 7 secara nilai dalam kelompok Produk Mesin dan Peralatan Mesin, sehingga kenaikan tarif untuk produk ini akan sangat berpengaruh pada kinerja ekspor Produk Mesin dan Peralatan Mesin ke Arab Saudi. 


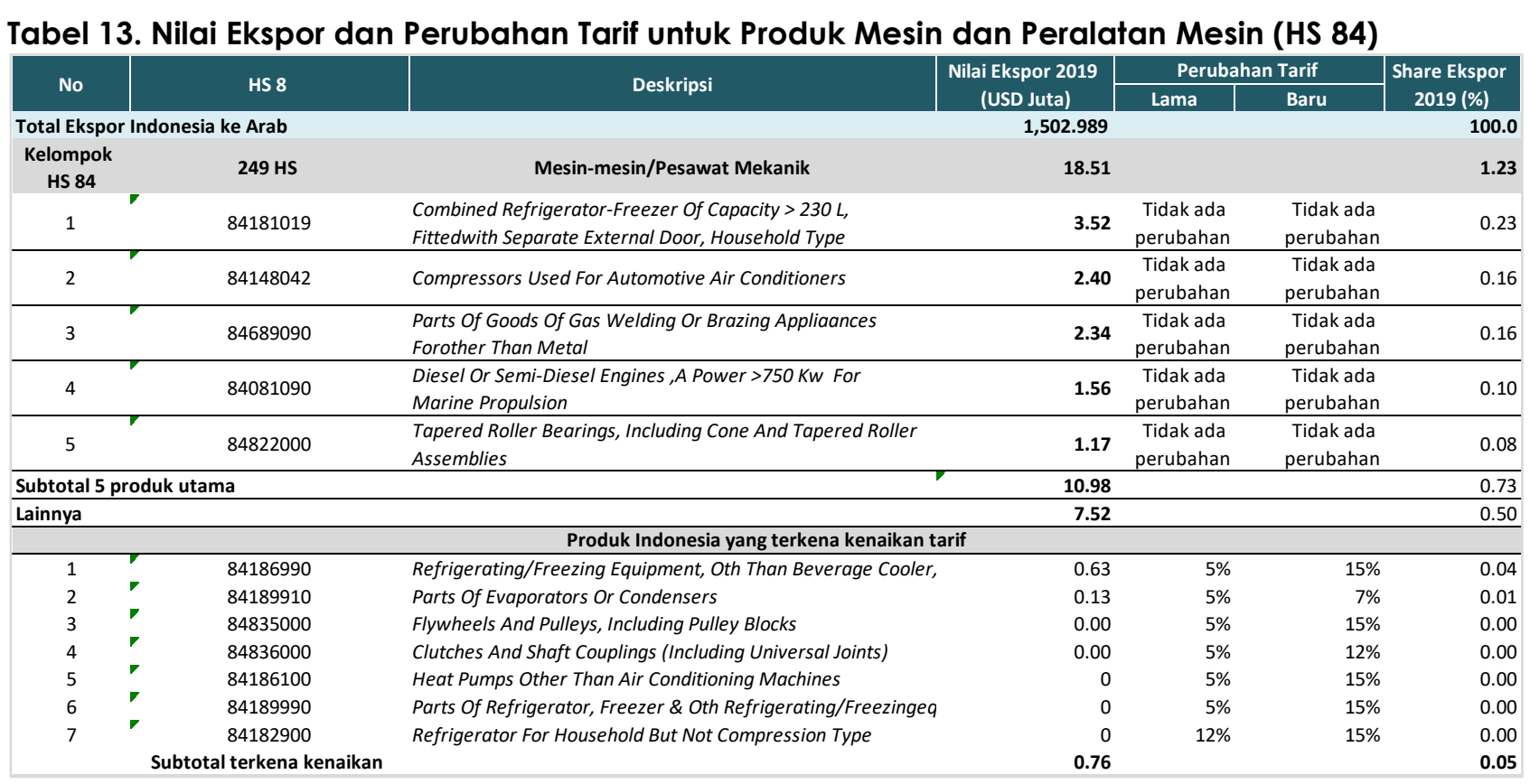

Sumber : Custom Saudi dan BPS (2020), diolah

Berdasarkan hasil analisis deskriptif di atas dapat dilihat bahwa secara umum kebijakan kenaikan tarif Arab Saudi atas beberapa produk impornya tidak berdampak secara signifikanbagi Indonesia terutama terhadap produk ekspor utama seperti Kendaraan bermotor dan suku cadang (HS 87), produk plastic (HS 39), produk elektronik (HS 85). Kemudian untuk produk utama Indonesia lainnya seperti minyak sawit (CPO) (HS 15), produk kayu (HS 44), dan produk daging dan ikan olahan(HS 16) tidak termasuk dalam daftar produk yang mengalami kenaikan tarif bea masuk di Arab Saudi sehingga tidak akan terdampak kebijakan ini (Custom Saudi dan BPS, 2020).

Namun demikian beberapa produk yang berpotensi mengalami penurunan ekspor akibat kenaikan tarif dapat terjadi untuk beberapakomoditi seperti produk kertas, benda-benda dari besi dan baja, besi dan baja, serat stapelbuatan, dan mesinmesin/pesawat mekanik. Untuk itu perlu mendapat perhatian dari pemerintah.

Untuk melihat dampak secara kuantitatif dapat dilakukan dengan menggunakan model analisis partial equilibrium (PE) maupun computable general equilibrium (CGE). Jika analisis deskriptif hanya memberikan gambaran kualitatif dampak terhadap masingmasing sektorberdasarkan data historis, model PE dan CGE dapat memprediksi besaran dampak secarakuantitatif. Kedua model ini umum digunakandalam melakukan analisis dampak kenaikan atau penurunan tarif bea masuk terhadap kinerja ekspor.

\section{KESIMPULAN}

Berdasarkan identifikasi produk utama ekspor Indonesia ke Arab Saudi, maka disimpulkanbahwa produk Indonesia yang terdampak akibat kenaikan tarif bea masuk di Arab Saudi adalah Produk Kertas (HS 48) dan Benda-benda dari Besi dan Baja (HS 73). Selain itu, produk ekspor Indonesia ke Arab Saudi diluar produk utama yang akan terdampak besar yaitu Besi dan baja (HS 72), Serat staple buatan (HS 55), serta Mesin dan Peralatan Mesin (HS 84).

Total nilai ekspor keseluruhan dari produk yang mengalami kenaikan tarif adalah USD 37,64 juta atau $2,90 \%$ dari total ekspor Indonesia ke Arab Saudi secara keseluruhan (Jan-Okt2020, yoy). 
Nilai ini relatif cukup kecil jika dibandingkan nilai ekspor Indonesia secara keseluruhan. Oleh karena itu dapat disimpulkan bahwa dampak

Berdasarkan hasil analisis dan kesimpulan, maka direkomendasikan perlu adanya sosialisasikepada pelaku usaha khususnya eksportir yang produknya dikenakan kenaikan tarifbea masuknya di Arab Saudi. Hal ini agar eksportir dapat melakukan langkah antisipasi dan penyesuaian atas kenaikan tarif tersebut termasuk upaya untuk dapat mencari alternatif pasar tujuan ekspor di negara lain. Selain itu untuk mempertahankan sekaligus meningkatkan akses pasar produk Indonesia di pasar Arab Saudi, maka perlu dioptimalisasikan Program Kerjasama di bidang perdagangan antara Indonesia dan Arab Saudi yang saat ini sedang dilaksanakan.

\section{REFERENSI}

Badan Pusat Statistik, 2020, Data perdaganganekspor dan impor Indonesia.

Bolaky, B., Freund, C, 2004, Trade, Regulations, and Growth. World Bank Policy Research Working Paper No. 3255.

Conn, B dan M.M. Badbouly, 2020, VAT and Customs Duty Increases in Saudi Arabia Implications for Investment into the Kingdom (Online), (https://www.jdsupra.com/legalnews/vat -and-customs-duty-increases-in-saudi41929, diakses 5 April 2021).

Custom Saudi. 2020. The new updated Custom Duty of Saudi Arabiarabia with Porter's Model. Jurnal of Business \& Industrial Marketing Vol.16(1. Page 59-68

Jasimuddin, S.M., Analyzing the Competitive advantages of Saudi A

Minardi, A., Taufik., N. Ridha. 2019. Impact of Trump Tarifs Policies on the Export of Indonesian Steel to the United States. International Journal of Innovation, Creativity, and Change. Vol. 10. Issue 7. kenaikan tarif terhadap ekspor Indonesia saat ini relatif kecil.

Saudi Arabia: Increased customs duties effective 20 June 2020,(Online) (https://home.kpmg/us/en/home/ins. ights/2020/06/tnf-saudi-arabia-increasedcustoms-duties-effective-20-june2020.html, diakses5 September 2020).

Sugiyono. 2009. Metode Penelitian Kuantitatif, Kualitatif dan R\&D. Bandung : Alfabeta

UNIDO. 2006. Industry 2020: Industrial Strategy to Enhance Diversification and competitiveness in the Kingdom of Saudi Arabia.

Wiyono, Gendro. 2011. Merancang Penelitian Bisinis dengan Alat Analisis SPSS 17.0 \& SmartPLS 2.0. Yogyakarta: Cetakan Pertama, UPP STIM YKPN.

World Trade Organization, 2020, Trade Policy Review of Saudi Arabia, (Online), (https://www.wto.org/english/tratop_e/tpr_ e/tp433_e.htm, diakses20 Oktober 2020). November 1995). 